\title{
Marinobacter daqiaonensis sp. nov., a moderate halophile isolated from a Yellow Sea salt pond
}

\author{
Lingyun Qu, Fengling Zhu, Jinxing Zhang, Chunlei Gao and Xiuqin Sun
}

Correspondence

Lingyun Qu

qly@fio.org.cn

Xiuqin Sun

xiuqin_sun@fio.org.cn

\author{
First Institute of Oceanography, State Oceanic Administration, Qingdao 266061, PR China
}

A Gram-negative, oxidase- and catalase-positive, moderately halophilic strain, designated $\mathrm{YCSA} \mathrm{O}^{\top}$, was isolated from sediment of Daqiao saltern in Qingdao, on the east coast of China. Growth occurred at $10-45{ }^{\circ} \mathrm{C}$, at $\mathrm{pH} 5-9$ and with $1-15 \% \mathrm{NaCl}$. Strain $\mathrm{YCSA} 40^{\top}$ showed the highest 16S rRNA gene sequence similarity to Marinobacter segnicrescens SS011B1-4 ${ }^{\top}(97 \%)$ and M. gudaonensis SL014B61 $\mathrm{A}^{\top}(96.9 \%)$ and 16S rRNA gene sequence phylogenetic analysis assigned the isolate to the genus Marinobacter. Strain $\mathrm{YCSA}_{4} \mathrm{~T}^{\top}$ contained $\mathrm{C}_{18: 1} \omega 9 \mathrm{c}(34.8 \%)$, $\mathrm{C}_{16: 0}(11.6 \%), \mathrm{C}_{19: 0}$ cyclo $\omega 10 c / \mathrm{C}_{19: 1} \omega 6 c(10.5 \%), \mathrm{C}_{16: 1} \omega 9 c(8.4 \%), \mathrm{C}_{17: 0}(6.3 \%)$ and $\mathrm{C}_{12: 0} 3-\mathrm{OH}(5.8 \%)$ as the predominant fatty acids. The DNA G+C content was $60.8 \mathrm{~mol} \%$ and the major ubiquinone was Q-9. These chemotaxonomic characters were all consistent with membership of the genus Marinobacter. DNA-DNA relatedness between the isolate and $M$. segnicrescens CGMCC $1.6489^{\top}$, M. gudaonensis CGMCC $1.6294^{\top}$ and other type strains of species of the genus Marinobacter was $\leqslant 30 \%$. On the basis of the aforementioned data, it was concluded that strain YCSA $40^{\top}$ represents a novel species of the genus Marinobacter, for which the name Marinobacter daqiaonensis sp. nov. is proposed. The type strain is $\mathrm{YCSA}^{\top}{ }^{\top}$ $\left(=\right.$ CGMCC $1.9167^{\top}=$ NCCB $100308^{\top}=$ LMG $\left.25365^{\top}\right)$.
Recent decades have seen a surge in the number of studies on micro-organisms that thrive in hypersaline environments because of their ability to adapt to highly saline conditions and produce enzymes that exhibit optimal activities at ranges of salt concentration and $\mathrm{pH}$ (Setati, 2010; Hedi et al., 2009). Many halophilic and halotolerant bacteria within different genera have been isolated from various marine and hypersaline environments, e.g. Marinobacter, Halomonas, Chromohalobacter, Salibacillus and Salinivibrio. In the course of an investigation of bacteria in a saltern in China, a Gram-negative and

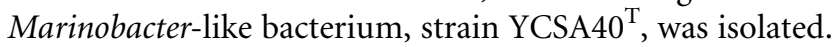

The genus Marinobacter, which is a member of the Gammaproteobacteria, was proposed by Gauthier et al. (1992) with one species, Marinobacter hydrocarbonoclasticus. At the time of writing, 27 species of the genus Marinobacter have been recognized, most of which are characterized chemotaxonomically as having ubiquinone-9 (Q-9) as the predominant ubiquinone, $\mathrm{C}_{16: 0}, \mathrm{C}_{18: 1} \omega 9 c$ and $\mathrm{C}_{16: 1} \omega 9 c$ as the predominant fatty acids and a DNA G $+\mathrm{C}$ content of 54-63.5 mol\% (Yoon et al., 2003, 2004, 2007; Gorshkova et al., 2003; Márquez \& Ventosa, 2005; Kim et al., 2006; Green et al., 2006; Xu et al., 2008; Wang et al., 2009; Aguilera et al., 2009; Kharroub et al., 2011). The

The GenBank/EMBL/DDBJ accession number for the 16S rRNA gene



Two supplementary figures are available with the online version of this paper. exception is Marinobacter lutaoensis, which contains Q-8 as the predominant ubiquinone and iso- $\mathrm{C}_{15: 0}$ as the major fatty acid (Shieh et al., 2003).

Strain YCSA40 ${ }^{\mathrm{T}}$ was isolated from sediment sampled at Daqiao saltern at Jimo, Qingdao, on the east coast of China $\left(36.50^{\circ} \mathrm{N} 120.82^{\circ} \mathrm{E}\right)$. Approximately $1 \mathrm{~g}$ sample was suspended in $100 \mathrm{ml}$ sterile seawater and vortexed for $10 \mathrm{~min}$. Isolates were obtained by incubating 10 -fold serial dilutions of the dispersed suspension on modified marine agar (2216E-S) (per litre seawater from the Yellow Sea: $5 \mathrm{~g}$ tryptone, $1 \mathrm{~g}$ yeast extract, $15 \mathrm{~g}$ agar; $\mathrm{pH}$ 7.5; $\mathrm{Qu}$ et al., 2011) for 7 days at $30{ }^{\circ} \mathrm{C}$. Strain YCSA $40^{\mathrm{T}}$ was purified by subcultivation on $2216 \mathrm{E}-\mathrm{S}$ agar for 5 days at $30{ }^{\circ} \mathrm{C}$. Culture purity was confirmed by homogeneity of the cell and colony morphologies. Strain YCSA $40^{\mathrm{T}}$ was maintained on 2216E-S agar at $30{ }^{\circ} \mathrm{C}$ and stored at $-80{ }^{\circ} \mathrm{C}$ in $2216 \mathrm{E}-\mathrm{S}$ broth supplemented with $30 \%(\mathrm{v} / \mathrm{v})$ glycerol.

The phenotypic characteristics of strain $\mathrm{YCSA}^{\mathrm{T}}{ }^{\mathrm{T}}$ were investigated using routine cultivation at $30{ }^{\circ} \mathrm{C}$ on marine agar 2216 (MA; Difco) with the $\mathrm{NaCl}$ concentration increased to $6.0 \%$. The reference strains Marinobacter segnicrescens CGMCC $1.6489^{\mathrm{T}}$, M. gudaonensis CGMCC $1.6294^{\mathrm{T}}$, M. bryozoorum DSM $15401^{\mathrm{T}}$ and M. lacisalsi LMG $24237^{\mathrm{T}}$ were used as controls. Cellular morphology and the presence of flagella were observed using transmission electron microscopy (H-7000; Hitachi). Gram-staining, catalase and oxidase activities, indole production, nitrate reduction and $\mathrm{H}_{2} \mathrm{~S}$ production from L-cysteine were 
examined according to standard methods (Dong \& Cai, 2001). Oxidative or fermentative utilization of glucose was determined following the description of Dong \& Cai (2001). Hydrolysis of starch, urea, aesculin, gelatin, Tweens 20 and 80 and DNA was assessed according to methods described elsewhere (Smibert \& Krieg, 1994; Dong \& Cai, 2001), using media supplemented with $6 \%$ $(\mathrm{w} / \mathrm{v})$ sea salts. Growth at $5-55{ }^{\circ} \mathrm{C}$ (at intervals of $\left.5{ }^{\circ} \mathrm{C}\right)$ and $42{ }^{\circ} \mathrm{C}$ was determined in marine broth (MB; Difco) with the $\mathrm{NaCl}$ concentration increased to $6.0 \%$. Growth with $0,0.5,1-8$ (at intervals of $1 \%$ ), 10, 12 and $15-30 \%$ (at intervals of $5 \%)(\mathrm{w} / \mathrm{v}) \mathrm{NaCl}$ was tested using LuriaBertani medium (Sambrook et al., 1989). Growth at $\mathrm{pH} 3-10$ (at intervals of $1 \mathrm{pH}$ unit) was tested in $\mathrm{MB}$ adjusted to the appropriate $\mathrm{pH}$ with $\mathrm{HCl}$ or $\mathrm{NaOH}$. Growth was determined by monitoring the $\mathrm{OD}_{660}$ with a spectrophotometer. Acid production from carbohydrates and enzyme production were carried out using the API 50 $\mathrm{CH}$ and API ZYM systems (bioMérieux), according to the manufacturer's instructions, with the $\mathrm{NaCl}$ concentration increased to $6.0 \%$ for the preparation of inocula. Carbon source assimilation was tested using the mineral medium solution of Shivaji et al. (2005), with each carbon source added to a concentration of $0.2 \%(\mathrm{w} / \mathrm{v})$. Growth was examined after incubation at $30{ }^{\circ} \mathrm{C}$ for 7 and 14 days (Gu et al., 2007). In addition, antibiotic susceptibility tests were performed on MA using filter-paper discs (Hangzhou Microbial Reagent Company) containing various antibiotics.

Cultures for fatty acid analysis were grown on MA at $30{ }^{\circ} \mathrm{C}$ for 3 days. Fatty acid methyl esters were prepared and analysed using the standard Microbial Identification System (MIDI) for an automated gas chromatographic analysis (Sasser, 1990). Isoprenoid quinones were obtained from whole cells according to the standard method (Dong \& Cai, 2001) and determined by HPLC according to Komagata \& Suzuki (1987). Genomic DNA for the determination of the $\mathrm{G}+\mathrm{C}$ content and 16S rRNA gene sequence analysis was prepared following the method of Rainey et al. (1996) and DNA purity was assessed by determining the $A_{280} / A_{260}$ and $A_{230} / A_{260}$ ratios. The $\mathrm{G}+\mathrm{C}$ content of the chromosomal DNA was determined according to the methods described by Mesbah \& Whitman (1989) using reversed-phase HPLC. DNA-DNA hybridization to determine genomic relatedness between strain $\mathrm{YCSA}^{\mathrm{T}} 0^{\mathrm{T}}$ and the reference strains was performed according to the description of Liu \& Shao (2005).

The 16S rRNA gene was amplified from extracted genomic DNA using PCR with universal primers $27 \mathrm{~F}$ and $1492 \mathrm{R}$, as described by Lane (1991). PCR products were purified and analysed as described previously ( $\mathrm{Qu}$ et al., 2011). 16S rRNA gene sequence similarities were investigated using the BLASTN search engine (Altschul et al., 1990) and the EzTaxon server (Chun et al., 2007), with which the sequences of related taxa were retrieved. After multiple sequence alignment using BioEdit version 7.0.9 (Tom Hall, Ibis Biosciences, Carlsbad, CA, USA), phylogenetic analysis was performed using MEGA version 4 (Tamura et al., 2007). A phylogenetic tree was reconstructed using the neighbourjoining method of Saitou \& Nei (1987) with distance options according to Kimura's two-parameter model and the tree topology was evaluated by bootstrapping based on 1000 replications. As a robustness test, an alternative phylogenetic tree was constructed using the minimumevolution method (Rzhetsky \& Nei, 1992).

Cells of strain YCSA40 ${ }^{\mathrm{T}}$ were Gram-negative, oxidase- and catalase-positive rods (approximately $0.4-0.7 \times 2.5-4.0 \mu \mathrm{m}$ ) and were motile with a single polar flagellum (Supplementary Fig. S1, available in IJSEM Online). Small cream, flat and circular colonies $(1.0-2.0 \mathrm{~mm}$ in diameter) were produced on MA after $2-3$ days at $30{ }^{\circ} \mathrm{C}$. Growth occurred at $10-45{ }^{\circ} \mathrm{C}$, at $\mathrm{pH} 5-9$ and with $1-15 \%(\mathrm{w} / \mathrm{v}) \mathrm{NaCl}$. Detailed results of the morphological and phenotypic characterization are given in the species description. Phenotypic features that differed between strain YCSA $40^{\mathrm{T}}$ and the reference strains are summarized in Table 1. Strain YCSA $40^{\mathrm{T}}$ contained $\mathrm{C}_{18: 1} \omega 9 c(34.8 \%), \mathrm{C}_{16: 0}(11.6 \%)$, $\mathrm{C}_{19: 0}$ cyclo $\omega 10 c / \mathrm{C}_{19: 1} \omega 6 c(10.5 \%), \mathrm{C}_{16: 1} \omega 9 c(8.4 \%)$, $\mathrm{C}_{17: 0}(6.3 \%)$ and $\mathrm{C}_{12: 0} 3-\mathrm{OH}(5.8 \%)$ as the predominant fatty acids (Table 2). The fatty acid composition of strain YCSA $40^{\mathrm{T}}$ was similar to those of the reference strains, although there were some differences in the proportions. Specifically, strain YCSA $40^{\mathrm{T}}$ had relatively large differences in the content of $\mathrm{C}_{16: 0}$ compared with $M$. segnicrescens CGMCC $1.6489^{\mathrm{T}}$ and M. gudaonensis CGMCC $1.6294^{\mathrm{T}}$ (11.6\% compared with $22.2-24.4 \%$ ) and $\mathrm{C}_{18: 1} \omega 9 \mathrm{c}$ compared with $M$. bryozoorum DSM $15401^{\mathrm{T}}$ and $M$. lacisalsi LMG $24237^{\mathrm{T}}$ (34.8\% compared with 41.2-42.2 \%) (Table 2). As the fatty acid profiles of these five strains were determined under the same conditions, these differences could be used to distinguish strain $\mathrm{YCSA} 40^{\mathrm{T}}$. Q-9 was the major quinone of strain YCSA $40^{\mathrm{T}}$, which is as given for the majority of members of the genus Marinobacter. The $\mathrm{G}+\mathrm{C}$ content of the chromosomal DNA of strain YCSA $40^{\mathrm{T}}$ was $60.8 \mathrm{~mol} \%$, which is within the range (54-63.5 mol\%) for the genus Marinobacter (Shieh et al., 2003; Kim et al., 2006). DNADNA relatedness between strain YCSA $40^{\mathrm{T}}$ and M. segnicrescens CGMCC $1.6489^{\mathrm{T}}$, M. gudaonensis CGMCC $1.6294^{\mathrm{T}}, M$. bryozoorum DSM $15401^{\mathrm{T}}$ and M. lacisalsi LMG $24237^{\mathrm{T}}$ was $30,20,10$ and $20 \%$, respectively. According to the cut-off value of $70 \%$ recommended by Wayne et al. (1987) for discriminating bacterial species, strain YCSA $40^{\mathrm{T}}$ represented a novel species.

Sequence analysis of the 16S rRNA gene (1410 bp) revealed that strain $\mathrm{YCSA}^{\mathrm{T}} 0^{\mathrm{T}}$ was affiliated with the genus Marinobacter. 16S rRNA gene sequence similarity ranged from a minimum of $92.8 \%$ with Marinobacter litoralis SW$45^{\mathrm{T}}$ to a maximum of $97 \%$ with M. segnicrescens SS011B1-4 $4^{\mathrm{T}}$. According to the cut-off value of 98-99\% 16S rRNA gene sequence similarity for the delineation of bacterial species (Stackebrandt \& Ebers, 2006), the divergence of the 16S rRNA gene sequences of strain $\mathrm{YCSA} 40^{\mathrm{T}}$ and other members of the genus Marinobacter supported the view that strain YCSA $40^{\mathrm{T}}$ represented a novel species. In addition, the 
Table 1. Differential characteristics of strain $\mathrm{YCSA} 40^{\top}$ and its closest phylogenetic neighbours

Strains: 1, Marinobacter daqiaonensis sp. nov. YCSA40 ${ }^{\mathrm{T}} ; 2$, M. segnicrescens CGMCC $1.6489^{\mathrm{T}} ; 3$, M. gudaonensis CGMCC $1.6294^{\mathrm{T}}$; 4, M. bryozoorum DSM $15401^{\mathrm{T}}$; 5. M. lacisalsi LMG $24237^{\mathrm{T}}$. All data were obtained in this study unless otherwise stated. All strains are Gram-negative, oxidase- and catalase-positive, motile with a single flagellum and positive for hydrolysis of Tween 20. All strains are negative for methyl red, Voges-Proskauer and nitrite reduction tests, gelatin and DNA hydrolysis and activities of $\alpha$-chymotrypsin, $\alpha$ - and $\beta$-galactosidases, trypsin, $\beta$-glucuronidase, $\alpha$ - and $\beta$-glucosidases, $\alpha$-mannosidase and $\alpha$-fucosidase. + , Positive; w, weakly positive; - , negative.

\begin{tabular}{|c|c|c|c|c|c|}
\hline Characteristic & 1 & 2 & 3 & 4 & 5 \\
\hline \multicolumn{6}{|l|}{ Cell dimensions $(\mu \mathrm{m})$} \\
\hline Width & $0.4-0.7$ & $0.6-0.7^{a_{\star}}$ & $0.3-0.5^{b}$ & $0.4-0.5^{c}$ & $0.6-0.9^{d}$ \\
\hline Length & $2.5-4.0$ & $0.9-1.2^{a}$ & $1.2-1.8^{b}$ & $1.0-1.3^{c}$ & $1.9-2.4^{d}$ \\
\hline $\mathrm{pH}$ range for growth & $5-9$ & $6-10$ & $6-9$ & $6-9$ & $5-9$ \\
\hline \multicolumn{6}{|l|}{ Temperature for growth $\left({ }^{\circ} \mathrm{C}\right)$} \\
\hline Range & $10-45$ & $10-45$ & $5-50$ & $5-42$ & $20-40$ \\
\hline Optimum & 30 & 35 & 35 & 30 & 35 \\
\hline Nitrate reduction & - & + & + & + & $-\left(+{ }^{d}\right)$ \\
\hline Indole production & - & + & - & - & - \\
\hline $\mathrm{H}_{2} \mathrm{~S}$ production & + & + & + & - & - \\
\hline \multicolumn{6}{|l|}{ Hydrolysis of: } \\
\hline Tween 80 & - & + & + & - & + \\
\hline Starch & + & - & + & - & + \\
\hline Urea & + & - & - & - & - \\
\hline \multicolumn{6}{|l|}{ Growth on: } \\
\hline Citrate & - & + & + & - & + \\
\hline D-Mannose & + & - & - & + & - \\
\hline L-Arabinose & - & $+\left(-{ }^{a}\right)$ & - & - & - \\
\hline Cellobiose & + & - & + & - & - \\
\hline Ethanol & + & - & + & $\mathrm{w}$ & - \\
\hline D-Sorbitol & - & $-\left(\mathrm{w}^{a}\right)$ & + & - & - \\
\hline Gluconate & + & - & + & - & + \\
\hline Glycerol & - & + & + & + & + \\
\hline myo-Inositol & - & $\mathrm{w}$ & $\mathrm{W}$ & - & - \\
\hline \multicolumn{6}{|l|}{ Enzyme activities (API ZYM) } \\
\hline Alkaline phosphatase & $\mathrm{w}$ & $\mathrm{w}$ & + & $\mathrm{W}$ & $\mathrm{W}$ \\
\hline Esterase (C4) & $\mathrm{w}$ & $\mathrm{w}$ & + & $\mathrm{w}\left(-{ }^{c}\right)$ & $\mathrm{w}$ \\
\hline Lipase $(\mathrm{C} 14)$ & - & - & + & - & - \\
\hline Leucine aminopeptidase & + & + & + & + & $\mathrm{w}$ \\
\hline Valine aminopeptidase & $\mathrm{w}$ & $\mathrm{w}$ & $\mathrm{W}$ & + & - \\
\hline Acid phosphatase & $\mathrm{w}$ & $\mathrm{w}$ & $\mathrm{w}$ & - & - \\
\hline$N$-Acetyl- $\beta$-glucosaminidase & $\mathrm{w}$ & + & + & + & + \\
\hline \multicolumn{6}{|l|}{ Sensitivity to $(\mu \mathrm{g})$ : } \\
\hline Novobiocin $(30)$ & + & - & + & + & - \\
\hline Streptomycin (10) & - & + & - & $-\left(+{ }^{c}\right)$ & - \\
\hline Tetracycline (30) & - & + & + & + & - \\
\hline Carbenicillin (100) & - & + & + & + & - \\
\hline Erythromycin (15) & - & + & + & + & - \\
\hline Ampicillin (10) & - & + & + & + & + \\
\hline DNA G $+C$ content $(\mathrm{mol} \%)$ & 60.8 & $62.2^{a}$ & $57.9^{b}$ & $59.6^{c}$ & $58.6^{d}$ \\
\hline
\end{tabular}

${ }^{\star}$ Data taken from: $a$, Guo et al. (2007); b, Gu et al. (2007); c, Romanenko et al. (2005); d, Aguilera et al. (2009).

phylogenetic analysis showed that strain YCSA40 ${ }^{\mathrm{T}}$ formed a distinct clade within the genus Marinobacter, which was supported by high bootstrap resampling values $(\geqslant 90 \%)$ in the neighbour-joining and minimum-evolution trees (Fig. 1 and Supplementary Fig. S2).
Thus, the combined phylogenetic, chemotaxonomic and phenotypic evidence clearly indicated that strain YCSA $40^{\mathrm{T}}$ should be classified in a novel species within the genus Marinobacter, for which the name Marinobacter daqiaonensis sp. nov. is proposed. 



and its closest phylogenetic neighbours

Strains: 1, Marinobacter daqiaonensis sp. nov. YCSA40 ${ }^{\mathrm{T}} ; 2, \mathrm{M}$. segnicrescens CGMCC $1.6489^{\mathrm{T}}$; 3, M. gudaonensis CGMCC $1.6294^{\mathrm{T}}$; 4, M. bryozoorum DSM $15401^{\mathrm{T}}$; 5. M. lacisalsi LMG $24237^{\mathrm{T}}$. Values are percentages of total fatty acids and were obtained in this study under identical growth conditions.

\begin{tabular}{|lccccc|}
\hline Fatty acid & $\mathbf{1}$ & $\mathbf{2}$ & $\mathbf{3}$ & $\mathbf{4}$ & $\mathbf{5}$ \\
\hline $\mathrm{C}_{10: 0}$ & 0.6 & 1.1 & 0.4 & 1.2 & 3.5 \\
$\mathrm{C}_{12: 0}$ & 3.8 & 6.2 & 5.6 & 4.9 & - \\
$\mathrm{C}_{12: 0} 3-\mathrm{OH}$ & 5.8 & 12.4 & 7.7 & 10.6 & 10.3 \\
$\mathrm{C}_{14: 0}$ & 0.4 & 2.0 & 0.9 & 1.0 & 1.0 \\
$\mathrm{C}_{16: 0} \mathrm{~N}$ alcohol & - & - & 1.9 & - & 1.0 \\
$\mathrm{C}_{16: 1} \omega 9 c$ & 8.4 & 8.9 & 5.8 & 3.2 & 6.5 \\
$\mathrm{C}_{16: 1} \omega 7 c / \mathrm{C}_{16: 1} \omega 6 c$ & 2.6 & - & 8.3 & 0.8 & - \\
$\mathrm{C}_{16: 0}$ & 11.6 & 22.2 & 24.4 & 17.3 & 16.1 \\
iso- $\mathrm{C}_{17: 1} \omega 9 c$ & - & - & 6.3 & - & - \\
$\mathrm{C}_{17: 1} \omega 8 c$ & 4.7 & - & 2.0 & 1.3 & 0.7 \\
$\mathrm{C}_{17: 0}$ & 6.3 & 0.7 & 1.5 & 3.8 & 1.2 \\
$10-\mathrm{Methyl} \mathrm{C}_{17: 0}$ & 0.9 & - & 1.9 & - & 1.2 \\
$\mathrm{C}_{18: 3} \omega 6 c(6,9,12)$ & - & - & 3.4 & - & - \\
$\mathrm{C}_{18: 2} \omega 6,9 c /$ anteiso- $\mathrm{C}_{18: 0}$ & - & - & 3.1 & - & - \\
$\mathrm{C}_{18: 1} \omega 9 c$ & 34.8 & 33.4 & 15.5 & 42.2 & 41.2 \\
$\mathrm{C}_{18: 1} \omega 7 c$ & 1.5 & - & 4.5 & 1.2 & 1.0 \\
$\mathrm{C}_{18: 0}$ & 3.3 & 4.0 & 4.1 & 6.0 & 5.5 \\
$\mathrm{C}_{19: 0}$ cyclo $\omega 10 c / \mathrm{C}_{19: 1} \omega 6 c$ & 10.5 & 9.2 & - & 6.5 & 11.5 \\
\hline
\end{tabular}

\section{Description of Marinobacter daqiaonensis sp.} nov.

Marinobacter daqiaonensis (da.qia.o.nen'sis. N.L. masc. adj. daqiaonensis of or belonging to the Daqiao Saltern, where the type strain was isolated).
Cells are Gram-negative, oxidase- and catalase-positive rods (0.4-0.7 $\mu \mathrm{m}$ wide and 2.5-4.0 $\mu \mathrm{m}$ long) and motile with a single polar flagellum. Colonies on MA are small, cream, flat and circular (1.0-2.0 $\mathrm{mm}$ in diameter) after 2-3 days at $30{ }^{\circ} \mathrm{C}$. Grows with $1-15 \%(w / v) ~ \mathrm{NaCl}$ (optimum 5-10\% $\mathrm{NaCl}$ ), at $10-45{ }^{\circ} \mathrm{C}$ (optimum $30{ }^{\circ} \mathrm{C}$ ) and at $\mathrm{pH} 5-9$ (optimum $\mathrm{pH}$ 7.5). Positive for $\mathrm{H}_{2} \mathrm{~S}$ production, but negative for nitrate reduction, nitrite reduction, indole production, oxidation and fermentation of glucose and Voges-Proskauer and methyl red tests. Hydrolyses Tween 20 , aesculin, starch and urease, but not Tween 80 , gelatin or DNA. With API $50 \mathrm{CH}$, positive only for 5-ketogluconate. With API ZYM, positive for esterase lipase (C8) and leucine aminopeptidase, weakly positive for alkaline phosphatase, esterase (C4), valine aminopeptidase, cystine aminopeptidase, acid phosphatase, naphthol-AS-BI-phosphoamidase and $N$-acetyl- $\beta$-glucosaminidase, but negative for lipase (C14), trypsin, $\alpha$-chymotrypsin, $\alpha$ - and $\beta$-galactosidases, $\beta$-glucuronidase, $\alpha$ - and $\beta$-glucosidases, $\alpha$-mannosidase and $\alpha$-fucosidase. Susceptible to ( $\mu \mathrm{g}$ per disc unless otherwise stated) nalidixic acid (30), novobiocin (30), polymyxin B (300 U), chloramphenicol (30) and rifampicin (5), but resistant to doxycycline (30), streptomycin (10), tetracycline (30), penicillin $\mathrm{G}(10 \mathrm{U})$, carbenicillin (100), vancomycin (30), neomycin (30), kanamycin (30), ampicillin (10), lincomycin (2), clindamycin (2), oxacillin (1) and erythromycin (15). As sole carbon and energy sources, utilizes Dmannose, cellobiose, adonitol, starch, ethanol, D-mannitol, $\mathrm{D}$-salicin, trehalose, $\mathrm{D}$-fructose, lactose, D-galactose, gluconate, D-glucose, maltose, propionate and ribose, but not sorbitol, aesculin, formate, myo-inositol, malonate, Larabinose, citrate, fumarate or glycerol. The main cellular fatty acids $(>10 \%)$ are $\mathrm{C}_{18: 1} \omega 9 c, \mathrm{C}_{16: 0}$ and $\mathrm{C}_{19: 0}$ cyclo

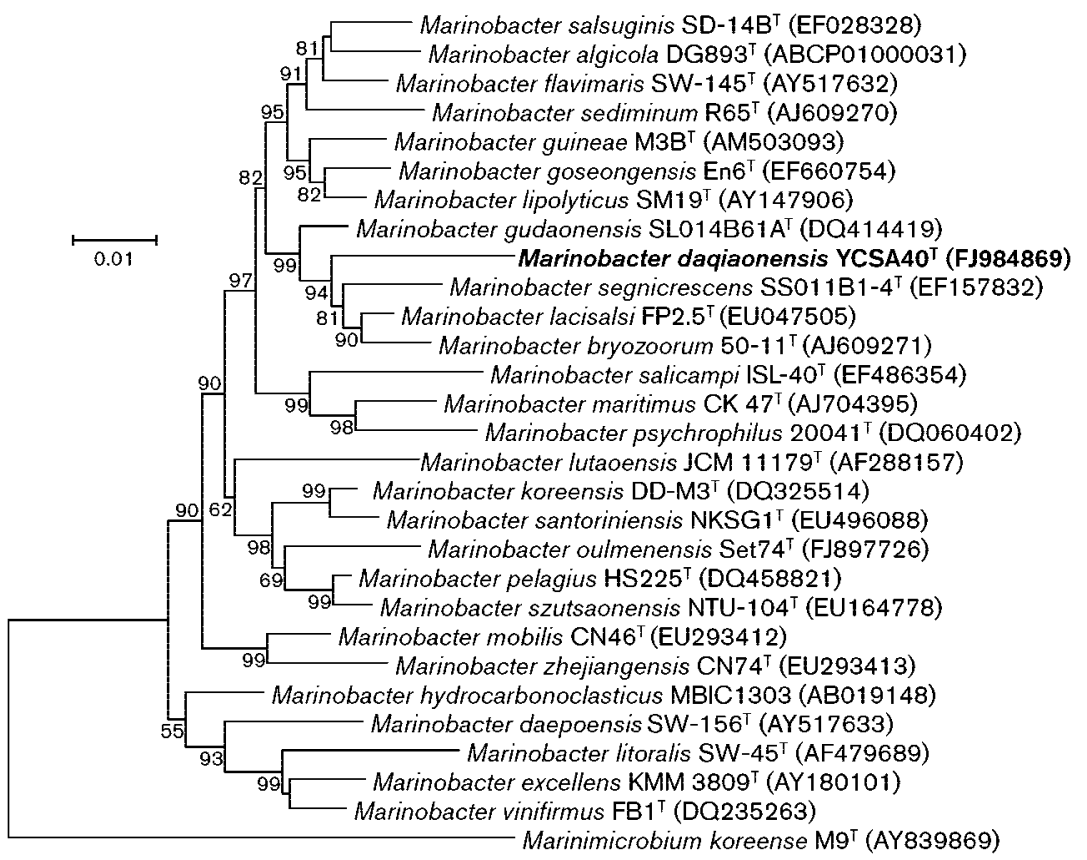

Fig. 1. Neighbour-joining phylogenetic tree based on 16S rRNA gene sequences, showing the position of strain $\mathrm{YCSA} \mathrm{O}^{\top}$ with respect to other members of the genus Marinobacter. Bootstrap values (>50\%) based on 1000 replications are shown at branch nodes. Marinimicrobium koreense $\mathrm{M}^{\top}$ was used as the outgroup. Bar, 0.01 substitutions per nucleotide position. 
$\omega 10 c / \mathrm{C}_{19: 1} \omega 6 c$. Q-9 is the major quinone. The DNA G+C content of the type strain is $60.8 \mathrm{~mol} \%$.

The type strain is YCSA $40^{\mathrm{T}}\left(=\right.$ CGMCC $1.9167^{\mathrm{T}}=\mathrm{NCCB}$ $100308^{\mathrm{T}}=\mathrm{LMG} 25365^{\mathrm{T}}$ ), isolated from sediment of Daqiao saltern, Jimo, Qingdao, on the east coast of China.

\section{Acknowledgements}

This work was supported by the National Natural Science Foundation of China (41006103), the Commonwealth Project of State Oceanic Administration, People's Republic of China (201105007), and International Science and Technology Cooperation of State Oceanic Administration, People's Republic of China (2007DFA30710).

\section{References}

Aguilera, M., Jiménez-Pranteda, M. L., Kharroub, K., GonzálezParedes, A., Durban, J. J., Russell, N. J., Ramos-Cormenzana, A. \& Monteoliva-Sánchez, M. (2009). Marinobacter lacisalsi sp. nov., a moderately halophilic bacterium isolated from the saline-wetland wildfowl reserve Fuente de Piedra in southern Spain. Int J Syst Evol Microbiol 59, 1691-1695.

Altschul, S. F., Gish, W., Miller, W., Myers, E. W. \& Lipman, D. J. (1990). Basic local alignment search tool. J Mol Biol 215, 403410.

Chun, J., Lee, J.-H., Jung, Y., Kim, M., Kim, S., Kim, B. K. \& Lim, Y.-W. (2007). EzTaxon: a web-based tool for the identification of prokaryotes based on $16 \mathrm{~S}$ ribosomal RNA gene sequences. Int J Syst Evol Microbiol 57, 2259-2261.

Dong, X.-Z. \& Cai, M.-Y. (editors) (2001). Determinative Manual for Routine Bacteriology. Beijing: Scientific Press (in Chinese).

Gauthier, M. J., Lafay, B., Christen, R., Fernandez, L., Acquaviva, M., Bonin, P. \& Bertrand, J. C. (1992). Marinobacter hydrocarbonoclasticus gen. nov., sp. nov., a new, extremely halotolerant, hydrocarbondegrading marine bacterium. Int J Syst Bacteriol 42, 568-576.

Gorshkova, N. M., Ivanova, E. P., Sergeev, A. F., Zhukova, N. V., Alexeeva, Y., Wright, J. P., Nicolau, D. V., Mikhailov, V. V. \& Christen, R. (2003). Marinobacter excellens sp. nov., isolated from sediments of the Sea of Japan. Int J Syst Evol Microbiol 53, 2073-2078.

Green, D. H., Bowman, J. P., Smith, E. A., Gutierrez, T. \& Bolch, C. J. S. (2006). Marinobacter algicola sp. nov., isolated from laboratory cultures of paralytic shellfish toxin-producing dinoflagellates. Int $J$ Syst Evol Microbiol 56, 523-527.

Gu, J., Cai, H., Yu, S.-L., Qu, R., Yin, B., Guo, Y.-F., Zhao, J.-Y. \& Wu, X.-L. (2007). Marinobacter gudaonensis sp. nov., isolated from an oilpolluted saline soil in a Chinese oilfield. Int J Syst Evol Microbiol 57, 250-254.

Guo, B., Gu, J., Ye, Y.-G., Tang, Y.-Q., Kida, K. \& Wu, X.-L. (2007). Marinobacter segnicrescens sp. nov., a moderate halophile isolated from benthic sediment of the South China Sea. Int J Syst Evol Microbiol 57, 1970-1974.

Hedi, A., Sadfi, N., Fardeau, M.-L., Rebib, H., Cayol, J.-L., Ollivier, B. \& Boudabous, A. (2009). Studies on the biodiversity of halophilic microorganisms isolated from El-Djerid salt lake (Tunisia) under aerobic conditions. Int J Microbiol 2009, 731786.

Kharroub, K., Aguilera, M., Jiménez-Pranteda, M.-L., GonzálezParedes, A., Ramos-Cormenzana, A. \& Monteoliva-Sánchez, M. (2011). Marinobacter oulmenensis sp. nov., a moderately halophilic bacterium isolated from brine of a salt concentrator. Int J Syst Evol Microbiol 61, 2210-2214.
Kim, B.-Y., Weon, H.-Y., Yoo, S.-H., Kim, J.-S., Kwon, S.-W., Stackebrandt, E. \& Go, S.-J. (2006). Marinobacter koreensis sp. nov., isolated from sea sand in Korea. Int J Syst Evol Microbiol 56, 2653-2656.

Komagata, K. \& Suzuki, K. (1987). Lipid and cell-wall analysis in bacterial systematics. Methods Microbiol 19, 161-207.

Lane, D. J. (1991). 16S/23S rRNA sequencing. In Nucleic Acid Techniques in Bacterial Systematics, pp. 115-175. Edited by E. Stackebrandt \& M. Goodfellow. Chichester: Wiley.

Liu, C. \& Shao, Z. (2005). Alcanivorax dieselolei sp. nov., a novel alkane-degrading bacterium isolated from sea water and deep-sea sediment. Int J Syst Evol Microbiol 55, 1181-1186.

Márquez, M. C. \& Ventosa, A. (2005). Marinobacter hydrocarbonoclasticus Gauthier et al. 1992 and Marinobacter aquaeolei Nguyen et al. 1999 are heterotypic synonyms. Int J Syst Evol Microbiol 55, 13491351.

Mesbah, M. \& Whitman, W. B. (1989). Measurement of deoxyguanosine/thymidine ratios in complex mixtures by high-performance liquid chromatography for determination of the mole percentage guanine + cytosine of DNA. J Chromatogr A 479, 297-306.

Qu, L., Lai, Q., Zhu, F., Hong, X., Sun, X. \& Shao, Z. (2011). Cohaesibacter marisflavi sp. nov., isolated from sediment of a seawater pond used for sea cucumber culture, and emended description of the genus Cohaesibacter. Int J Syst Evol Microbiol 61, 762-766.

Rainey, F. A., Ward-Rainey, N., Kroppenstedt, R. M. \& Stackebrandt, E. (1996). The genus Nocardiopsis represents a phylogenetically coherent taxon and a distinct actinomycete lineage: proposal of Nocardiopsaceae fam. nov. Int J Syst Bacteriol 46, 1088-1092.

Romanenko, L. A., Schumann, P., Rohde, M., Zhukova, N. V., Mikhailov, V. V. \& Stackebrandt, E. (2005). Marinobacter bryzoorum sp. nov. and Marinobacter sediminum sp. nov., novel bacteria from the marine environment. Int J Syst Evol Microbiol 55, 143-148.

Rzhetsky, A. \& Nei, M. (1992). A simple method for estimating and testing minimum-evolution trees. Mol Biol Evol 9, 945-967.

Saitou, N. \& Nei, M. (1987). The neighbor-joining method: a new method for reconstructing phylogenetic trees. Mol Biol Evol 4, 406425.

Sambrook, J., Fritsch, E. F. \& Maniatis, T. (1989). Molecular Cloning: a Laboratory Manual, 2nd edn. Cold Spring Harbor, NY: Cold Spring Harbor Laboratory.

Sasser, M. (1990). Identification of bacteria by gas chromatography of cellular fatty acids, MIDI Technical Note 101. Newark, DE: MIDI Inc.

Setati, M. E. (2010). Diversity and industrial potential of hydrolaseproducing halophilic/halotolerant eubacteria. Afr J Biotechnol 9, 1555-1560.

Shieh, W. Y., Jean, W. D., Lin, Y.-T. \& Tseng, M. (2003). Marinobacter lutaoensis sp. nov., a thermotolerant marine bacterium isolated from a coastal hot spring in Lutao, Taiwan. Can J Microbiol 49, 244-252.

Shivaji, S., Gupta, P., Chaturvedi, P., Suresh, K. \& Delille, D. (2005). Marinobacter maritimus sp. nov., a psychrotolerant strain isolated from sea water off the subantarctic Kerguelen islands. Int J Syst Evol Microbiol 55, 1453-1456.

Smibert, R. M. \& Krieg, N. R. (1994). Phenotypic characterization. In Methods for General and Molecular Bacteriology, pp. 607-654. Edited by P. Gerhardt, R. G. E. Murray, W. A. Wood \& N. R. Krieg. Washington, DC: American Society for Microbiology.

Stackebrandt, E. \& Ebers, J. (2006). Taxonomic parameters revisited: tarnished gold standards. Microbiol Today 33, 152-155.

Tamura, K., Dudley, J., Nei, M. \& Kumar, S. (2007). MEGA4: molecular evolutionary genetics analysis (MEGA) software version 4.0. Mol Biol Evol 24, 1596-1599. 
Wang, C.-Y., Ng, C.-C., Tzeng, W.-S. \& Shyu, Y. T. (2009). Marinobacter szutsaonensis sp. nov., isolated from a solar saltern. Int J Syst Evol Microbiol 59, 2605-2609.

Wayne, L. G., Brenner, D. J., Colwell, R. R., Grimont, P. A. D., Kandler, O., Krichevsky, M. I., Moore, L. H., Moore, W. E. C., Murray, R. G. E. \& other authors (1987). International Committee on Systematic Bacteriology. Report of the ad hoc committee on reconciliation of approaches to bacterial systematics. Int J Syst Bacteriol 37, 463-464.

Xu, X.-W., Wu, Y.-H., Wang, C.-S., Yang, J.-Y., Oren, A. \& Wu, M. (2008). Marinobacter pelagius sp. nov., a moderately halophilic bacterium. Int J Syst Evol Microbiol 58, 637-640.
Yoon, J.-H., Shin, D.-Y., Kim, I.-G., Kang, K. H. \& Park, Y.-H. (2003). Marinobacter litoralis sp. nov., a moderately halophilic bacterium isolated from sea water from the East Sea in Korea. Int J Syst Evol Microbiol 53, 563-568.

Yoon, J.-H., Yeo, S.-H., Kim, I.-G. \& Oh, T.-K. (2004). Marinobacter flavimaris sp. nov. and Marinobacter daepoensis sp. nov., slightly halophilic organisms isolated from sea water of the Yellow Sea in Korea. Int J Syst Evol Microbiol 54, 1799-1803.

Yoon, J.-H., Lee, M.-H., Kang, S.-J. \& Oh, T.-K. (2007). Marinobacter salicampi sp. nov., isolated from a marine solar saltern in Korea. Int $J$ Syst Evol Microbiol 57, 2102-2105. 